\title{
Una traducción introductoria a Jean-Joseph Rabearivelo
}

\section{An Introductory Translation to Jean-Joseph Rabearivelo}

\author{
Alejandro Merlín Alvarado \\ Facultad de Filosofía y Letras \\ Universidad Nacional AutónOMa de MÉXICO \\ México
}

\section{Semblanza biográfica}

Jean-Joseph Rabearivelo nació en 1903, en Antananarivo, cuando Madagascar era colonia francesa. Como escritor, practicó todos los géneros tradicionales de la literatura: el teatro, la poesía y la narrativa; fue periodista, crítico literario, traductor y corrector.

A los trece años dejó la educación formal. Si bien recibió una educación malgache, decidió aprender francés, solo, a los 17 años, acaso motivado por la ambición de escalar socialmente y por un interés genuino de estudiar e imitar la poesía francesa. Comenzó a escribir desde muy joven en la prensa local, para después concentrarse en publicar sus propios libros. Por esos años fue contratado como corrector de la imprenta de Imerina, trabajo que conservó hasta su muerte - la imprenta principal de la prensa de la región-. Desde adolescente estuvo convencido de que sería el primer intelectual de su país, como puede constatarse en sus diarios.

Junto con un grupo de intelectuales que querían que Madagascar se acercara a la cultura occidental y que se proponían competir con los poetas franceses (Meitinger: 2010), fundó la falange Rabearivelo; él y sus colegas escritores colaboraron durante unos años en la revista Mpanoro-talana, escaparate generacional.

Durante estos años formativos, según puede apreciarse en sus diarios, publicados recientemente por un grupo de especialistas en sus obras completas con el título de Les Calepins bleus, leyó sobre todo poetas franceses parnasianos y simbolistas (Nerval, Baudelaire, Gautier): sus primeras publicaciones reflejaban el apego a la forma tradicional del verso, escribía sonetos, principalmente, o también poemas en cuartetos alejandrinos con rima consonante (Soirs malgaches, Quelques sonnets).

Ya con 25 años, sin todavía modificar del todo su estilo, publicó Volumes y Chants d'Iarive, poemarios con un cierto costumbrismo tropical, en los que persiste 
una sensación de encierro, una suerte de lamentación de la tierra natal, con un vocabulario típico del simbolismo francés (Rabearivelo, 2010: 323), y referencias imitadas a la tradición grecolatina. En estos libros, todavía se notaba su esfuerzo por demostrar sus habilidades como versificador y complacer a una metrópoli literaria.

Algunos años más tarde, leyó a nuevos poetas franceses, en especial porque, a la par de su trabajo como corrector de pruebas de imprenta, también era traductor: por entonces tradujo a Paul Valéry, quien también influyó mucho en su obra. Tras la lectura de Laforgue, Moréas, Toulet, pensó en acercarse al verso libre y experimentar con una forma poética propia del malgache, los hain-teny. ${ }^{1}$

Por el oficio de traductor, en una combinación singular entre traducir canciones de su lengua materna y conocer estilos poéticos vanguardistas, el poeta joven cambió el foco de su atención: ya no era un francocentrista literario, y ocurrió una transformación dentro de él que lo hizo escribir nuevamente poesía en malgache y traducirse a sí mismo, experimentar e incorporar otros estilos más personales. Además, no conforme con el conocimiento de la cultura francesa, aprendió también español. De hecho, uno de sus últimos libros está dedicado a Alfonso Reyes; leyó con mucho entusiasmo las Soledades, de Góngora, y los ensayos del mexicano sobre el Siglo de Oro español lo deslumbraron.

Quizá por eso, sus dos poemarios más ambiciosos sean de la época en que produjo una buena parte de su obra de manera bilingüe, después de haber estudiado la poesía tradicional de su país, cuando ya tenía más de 30 años.

Decide crear, escribir poemas en malgache y en francés al mismo tiempo. Así nacen sus libros de poesía más originales y significativos: Casi sueños (Sari-Nofy) y Traducido de la noche (Nadika Tamin'ny Alina), entre 1931 y 1934. El vocabulario es completamente distinto, ya no hay una restricción formal tradicional y escribe en verso libre, con una cadencia y un juego estilístico vanguardistas. En sus diarios, puede verse cómo se sentía acorralado en el dilema de practicar un género literario inspirado por el colonizador que minimizaba o era indiferente a lo que el poeta decía; por ser un colonizado estaba dividido entre escribir en su lengua y ser leído y admirado en Francia, cosa que difícilmente pasaría si no publicaba en francés. Sufría de una idolatría de las figuras literarias europeas que inspiraba un rechazo cultural de sí mismo y a la vez una reivindicación de su cultura (Rabearivelo, 1936: 1040-1050). Quizá a eso se deba la originalidad de ambos poemarios: Rabearivelo no sólo imitó de una tradición literaria metropolitana, sino que buscó incorporar formalmente su

\footnotetext{
1 "Los hainteny o hain-teny son un tipo de poemas [...] que condensan en metáforas extraordinariamente densas y con juegos de palabras y de sonidos sumamente sofisticados, conceptos, sentimientos y efectos poéticos de gran complejidad fónica y semántica. Ningún hainteny es métricamente similar a otro: el número de sílabas, el número de versos, a veces hasta el número de estrofas cuando hay varias, son siempre tan cambiantes como las tornasoladas imágenes y metáforas que reflejan. Casi podría decirse que los hainteny son poesía que se empeña en huir de moldes y de reglas, y que el único compromiso que busca es el de la elaboración de las imágenes, las metáforas y las aliteraciones más densas que la más experimentada sensibilidad poética pueda alumbrar.” (Pedrosa y Rabarijaona, 2009)
} 
propia tradición, y no sólo en el vocabulario o en los temas, como suele ser el caso, sino también en el ritmo, en la prosodia, en la cadencia, en la noción misma de la poesía: los hain-teny eran poemas llenos de aliteraciones, juegos fónicos y léxicos que sacaban provecho de la plasticidad del malgache, pero que se perdían al pasar al francés. Por eso, decide escribir de tal forma que, al traducirse a sí mismo, pudiera reflejar algo de dicha plasticidad. Más que autotraducirse, podría hablarse de que escribió de manera bilingüe, aunque pueden notarse algunas rarezas sintácticas en sus poemas en francés, producto de ese esfuerzo bicultural por escribir poesía. De esta última etapa, su rasgo más sobresaliente es la capacidad que logró para construir metáforas originales, a veces incluso desconcertantes; ya no es complaciente con un lector extranjero: se vuelve original pero no exotizante, domina sus recursos y convierte su entorno en un campo metafórico coherente y personal.

Jean-Joseph Rabearivelo era un poeta ambicioso, obsesionado con su consagración: "Une petite manière de vengeance sur ce siècle - sur ce temps - sans foi et ingrat. J'aurais ma légende. Une légende qui sera à souhait grossie et, à souhait aussi, à grands coups d'érudition, ramenée à ses justes proportions...(10/1/34)"”2 (Rabearivelo, 2010: 41). El deseo de controlar su imagen de genio era tan fuerte y determinante que propició incluso fantasías suicidas. Rabearivelo sentía que jamás sería correspondido por el mundo editorial francés, temía ser olvidado y estaba convencido de que el hecho de no haber sido leído por escritores franceses — pese a sus intentos de publicar y dar a conocer su obra en Francia - lo había sumido en una profunda depresión, de la cual ni siquiera el hecho de ser un poeta famoso en su país lo iba a curar. Dejó una carta suicida donde resume la "inseguridad intelectual" que había padecido en los últimos años. Rabearivelo, "suicida de la sociedad colonial", se mató en junio de 1937 de manera casi ceremonial: antes de envenenarse, escribió algunas cartas de despedida y escribió un poema en el que se lamentaba por su cultura y se despedía de un libro de Baudelaire. De hecho, redactó en su diario todavía algunas palabras mientras el veneno hacía efecto en su cuerpo. Tenía 34 años.

Léopold Sédar Senghor lo dio a conocer fuera de Madagascar en su Anthologie de la nouvelle poésie nègre et malgache (1948). Afortunadamente, ya existe una versión en español de sus poemarios más célebres, publicados por Hiperión en el año 2000.

\section{Estilo de la traducción}

Acerca de la traducción, sólo quiero aclarar que escogí este poema por representar bien la obra de Jean-Joseph Rabearivelo. Me pareció que esta traducción debía ser un poema en español derivado del original mas no dependiente. Pese a que se

\footnotetext{
${ }^{2}$ Será una forma de venganza de este siglo — de esta época—, ingrato y sin fe. Y tendré mi leyenda. Una leyenda que será agrandada a placer y, también a placer y a golpes de erudición, será llevada a su justa proporción...
} 
presenten bilingües, cosa que sin duda ayuda a apreciar el proceso para quienes hablan ambas lenguas, el poema en español debe ser eso precisamente: un poema. Si comprendemos la obviedad de que el original precede cronológica y lógicamente a la traducción, aceptamos entonces que también debe guiar la lógica creativa de la traducción. En ese sentido, la lógica textual del poema en francés no es sólo expresarse discursivamente, sino además hacerlo poéticamente, es decir, de forma eufónica, rítmica, imaginativa. Se trata, pues, de una traducción target oriented, y, en el sentido teórico de Gideon Toury, es una traducción literaria:

[...] literary translation involves the imposition of "conformity conditions" beyond the linguistic and/or general-textual ones, namely, to models and norms which are deemed literary at the target end. It thus yields more or less well-formed texts, from the point of view of the literary requirements of the recipient culture, at various possible costs in terms of the reconstruction of the features of the source text. (Toury: 2012)

Naturalmente, no se trata de una carta abierta al traductor so pretexto de lo literario. Se trata tan sólo de establecer el marco lógico de la traducción desde una aceptabilidad dentro de la cultura literaria receptora para que la traducción pueda ser leída independientemente de su original.

Me pareció que una traducción literal, y especialmente calcada, no iba a sostener una lógica formal, aunque sostuviera la discursiva: un poema en español, al igual que en francés, es ambas cosas: discurso y forma. De tal suerte que encabalgué algunos versos, para que la cantidad de sílabas no entorpeciera la prosodia; también, escogí algunas palabras que pudieran equilibrar la cantidad de sílabas fuertes a final de verso; lo mismo con la puntuación, escasa como en el original; en cuanto al vocabulario, me vi obligado — como cualquier poeta haría - a escoger las palabras no sólo por su significado, sino también por su sonido. Establecí como límite de esta lógica el sentido del poema: siempre que tuviera que elegir una palabra menos precisa, digamos, no debía salirse del campo semántico de la palabra en francés, debía estar relacionada y de alguna forma implicar el mismo sentido. Para traducir soir por atardecer, ni por tarde ni por noche, recurrí a la versión malgache del poema: Rabearivelo escribió hariva, que significa anochecer, precisamente (Webber, 1855: 742). Intercalé el significado entre noches y atardeceres, según ameritaba el verso del poema, aprovechando la ambivalencia que soir puede tener en español.

Como era deseable que se mantuviera la tensión entre el discurso y la forma eufónica del poema, leí repetidas veces ambos poemas en voz alta, procurando corregir la cadencia o la prosodia ahí cuando resultaban una anómala, y la otra cacofónica. El resultado debía ser, pues, un poema que pudiera leerse en español precisamente como poema. Volví explícitas algunas preposiciones o pronombres cuando parecía demasiado oscuro el significado y omití otras. En mi traducción hay más versos; busqué encabalgar la lectura como suele hacerse en la poesía contemporánea para crear el efecto de la puntuación omitida. 
No sobra decir que Jean-Joseph Rabearivelo, como traductor, se concebía como un passeur de langues. Me pareció correcto hacer un esfuerzo por imitarlo. Ofrezco esta versión de "Atardeceres de invierno", poema incluido en Casi sueños:

\section{Soirs d'hiver}

Je préfère encore les soirs

où je sens que ma voix se fait indécise

comme celle des enfants et des jeunes filles

et des femmes qui ne vivent plus que de souvenirs -

peur ou regret, angoisse ou recueillement ? -

Je préfère encore les soirs

où le soleil convoite les grappes de raisin

que la nuit cueille partout où il a déjà passé ;

je les préfère, moi,

aux matins que je ne puis voir,

mes fenêtres s'ouvrant sur le ponant,

et l'autre mur étant doublé par les ombres voisines

qui se bombent comme des loupes sur le garrot d'un taureau.

Et les soirs d'hiver où il bruine

sur les paysages d'Iarive

qui me rappellent Utrillo,

les longs soirs de bruine

où tout frissonne, jusqu' au bonheur de l'enfant

qui tète en paix comme veau en été,

et jusqu'à la tristesse qui fait ombre

dans les yeux de la vielle fille

qui regarde en vain autour d'elle.

Iarive, Iarive,

étendue sur l'herbe tendre des rizières

où le vent et la clarté se fuient et se retrouvent,

isolée sur les rochers comme des cactées,

accroupie comme un bœuf surpris par la nuit

ou élancée comme un pousse de bambou au bord de l'eau,

c'est toujours au seuil des soirs d'hiver

que tu es surtout toi-même.

Tu n'y es que songes et que mélancolie,

ô tombeau végétal

érigé comme une maison froide

qu'entourent des lianes

défaites par les quatre vents qui courent

à la poursuite de leurs sangliers

qui beuglent près de ma porte. 


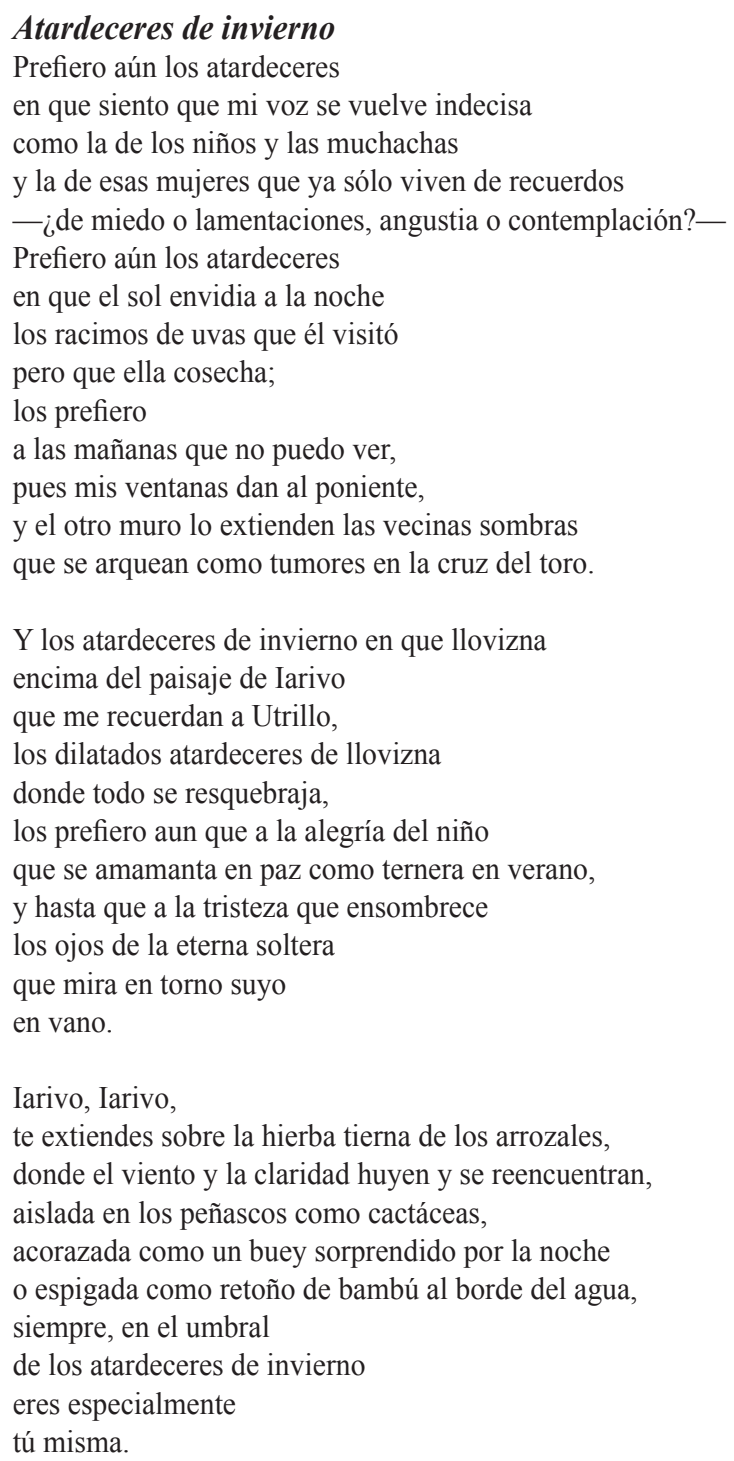

Sólo eres sueños y melancolía:

ahí, oh, tumba vegetal,

construida como una casa fría

que las lianas envuelven,

deshechas por los cuatro vientos que corren

a la caza de los jabalíes

que braman frente a mi puerta. 


\section{Referencias bibliográficas}

Meitinger, Serge. (2010). "Introduction Générale ou La vie écrite selon JeanJospeh Rabearivelo". En J. J. Rabearivelo, Euvres complètes. Tome I. Le diariste (Les Calepins bleus), l'épistolier, le moraliste. París: CNRS Éditions, Présence Africaine Éditions.

Meitinger, Serge. (2012). "Le portrait d'une vocation". En J. J. Rabearivelo, Euvres complètes. Tome II. Le Le poète, le narrateur, le dramaturge, le critique, le passeur de langues, l'historien. París: CNRS Éditions.

Pedrosa, José Manuel; y RabariJaOna, Harinirinjahana. (2009). La selva de los hainteny. Poesía tradicional de Madagascar. Madrid: Universidad de Alcalá, IIF-UNAM, Centro de Estudios Cervantinos.

RABEARIVElo, Jean Joseph. (2000). Casi sueños. Traducido de la noche. Madrid: Hiperión.

RABEARIVELO, Jean Joseph. (2010). "Harivan-dririnina”. En CEuvres complètes. Tome II. Le Le poète, le narrateur, le dramaturge, le critique, le passeur de langues, l'historien. París: CNRS Éditions.

Toury, Gideon. (2012). Descriptive Translation Studies—and Beyond. Filadelfia: John Benjamin Publishing Company.

WeBBER, Joseph. (1855). Dictionnaire français-malgache, rédigé par les missionnaires catholiques de Madagascar, et adapté aux dialectes de toutes les provinces... [libro digitalizado]. Île Bourbon. Recuperado el 15 de enero de 2020 de https://gallica.bnf.fr/ark:/12148/bpt6k824575/f745.item.r=malgache 